\title{
GMR
}

\section{Multiple genetic resistances in Capsicum spp}

\author{
C.S. Bento, A.G. de Souza, C.P. Sudré, S. Pimenta and R. Rodrigues \\ Laboratório de Melhoramento Genético Vegetal, \\ Universidade Estadual do Norte Fluminense Darcy Ribeiro, \\ Campos dos Goytacazes, RJ, Brasil \\ Corresponding author: R. Rodrigues \\ E-mail: rosana@uenf.br
}

Genet. Mol. Res. 16 (3): gmr16039789

Received July 28, 2017

Accepted September 11, 2017

Published September 27, 2017

DOI http://dx.doi.org/10.4238/gmr16039789

Copyright $\left({ }^{\circ} 2017\right.$ The Authors. This is an open-access article distributed under the terms of the Creative Commons Attribution ShareAlike (CC BY-SA) 4.0 License.

\begin{abstract}
This study aimed to identify Capsicum genotypes with resistance to bacterial spot (BS), anthracnose and Pepper yellow mosaic virus (PepYMV). Fifty-four genotypes of Capsicum spp were evaluated. Resistance reaction against BS was evaluated using three replicates, testing hypersensitivity and quantitative resistance in leaves. After evaluation, inoculated leaves were detached from the plants, being then cultivated until reproductive stage for evaluations anthracnose resistance in immature and mature fruit, totalizing 18 fruits per genotype. For PepYMV resistance was performed with five replications. Each genotype reaction was evaluated by a scoring scale, using the area under the disease progress curve for each pathosystem, and incubation period for the three systems. The latent period was evaluated only for the pathosystem Capsicum-Colletotrichum gloeosporioides. Means were grouped by the Scott-Knott test. Measures of dissimilarity matrix among the genotypes were obtained by Gower's algorithm and the grouping was obtained by the UPGMA clustering method. The accessions belonging to the Capsicum frutescens were the most susceptible to the three diseases. At least one genotype of Capsicum baccatum var. pendulum, Capsicum annuum, and Capsicum chinense showed resistance potential to BS and PepYMV, for use in breeding
\end{abstract}

Genetics and Molecular Research 16 (3): gmr16039789 
programs. The accession UENF 1381 (C. annuum) was resistant to the three pathogens.

Key words: Xanthomonas euvesicatoria; Colletotrichum gloeosporioides; Chili pepper; Pepper yellow mosaic virus

\section{INTRODUCTION}

In recent years, consumption and production of cultivars of plants of the genus Capsicum have been growing worldwide. Chilies and sweet peppers are in the fourth and eighth positions regarding in growing area of vegetable production around the world (FAOSTAT, 2012). In 2013, it reached a world production of 31.14 million tons within nearly two million hectares (FAOSTAT, 2013). Such demand is increasing given a widening of uses. Traditionally, this plant is used for color, flavor, and aroma in food preparations. Lately, sweet peppers and chilies have been increasingly used for ornamental purposes, as well as in food and pharmaceutical industries. A few substances extracted from Capsicum fruit may induce formation and improve connections between neurons such as epigenin (Souza et al., 2015), besides being applied to cancer treatments as capsaicin (Clark and Lee, 2016), among other uses. These applications provide more visibility to this plant genus, boosting the development of new varieties to meet all different demands.

Diseases compose the main limiting factor of Capsicum growing. These include bacterial spot (Xanthomonas spp), anthracnose (Colletotrichum spp), and Pepper yellow mosaic virus (PepYMV) (Riva-Souza et al., 2009; Bento et al., 2013; Diao et al., 2017).

In Brazil, bacterial spot (BS) is mostly caused by Xanthomonas euvesicatoria (Areas et al., 2015). This disease is difficult to control in the field, causing great losses to the farmers. In addition, it is highly destructive, being favored by high temperatures and humidity (Stall et al., 2009). As prevention and control measures, it is recommended using healthy seeds and seedlings, removing crop remains, besides using crop rotation and resistant cultivars (Pinto et al., 2011). The latter is the most effective among the control measures. Several studies have aimed to understand the interaction between Capsicum and Xanthomonas (Jones et al., 2004; Vallejos et al., 2010; Ryan et al., 2011; Potnis et al., 2012), seeking for resistance sources (Costa et al., 2002; Riva-Souza et al., 2009; Moreira et al., 2013) by characterization of the gene expression (Jones et al., 1998; Riva et al., 2004b; Kiss et al., 2016), genetic inheritance (Riva et al., 2004a), developing molecular markers for resistance genes (Holdsworth and Mazourek, 2015), and use of transgenics (Zipfel and Jones, 2015). Despite these studies, few pure line cultivars that are resistant to BS are available in the seed market. Pimenta et al. (2016) developed and protected two cultivars of pepper (Capsicum annuиm var. annuum) with $\mathrm{BS}$ resistance, being the first species protected in Brazil.

Another important disease affecting plants of the Capsicum genus is anthracnosis, which is caused by a complex of Colletotrichum species. At least 15 species of this genus were identified from a collection of 1285 isolates (Diao et al., 2017), among which are $C$. fioriniae, C. fructicola, C. gloeosporioides, C. scovillei, and C. truncatum (syn. C. capsici). In this identification study, seven species were reported for the first time in chili peppers (C. aenigma, C. cliviae, C. endophytica, C. hymenocallidis, C. incanum, C. karstii, and C. viniferum); and other three new ones were recognized and described (C. conoides, C. grossum, and $C$. liaoningense). Anthracnose is caused by a cosmopolitan pathogen; it can damage an

Genetics and Molecular Research 16 (3): gmr16039789 
entire plant, being the fruit mostly impacted in both pre- and post-harvest. This disease control is regularly made through fungicide spraying; however, it oftentimes has a slow efficiency depending on environmental conditions, such as temperatures and high humidity and/ or frequent and severe rainfalls (Haddad et al., 2003). In this case, plant-breeding programs search for cultivars showing steady resistance and against broad-spectrum diseases (Reis et al., 2009).

PepYMV is a member of the Potyvirus genus and occurs naturally in crops, provoking great losses since it is easily spread. The main symptoms are leaf twisting, mosaic development, dwarfism, and fruit deformity (Maciel-Zambolim et al., 2004; Bento et al., 2013). Seven genic loci have already been identified in pvr series imparting resistance to the Potyvirus genus in Capsicum plants. Among them, five are recessive ( $p v r 1, p v r 2, p v r 3, p v r 5$, and $p v r 6)$ and two are dominant (Pvr4 and Pvr7) (Parrela et al., 2002; Nogueira et al., 2012). Identifying and manipulating these or other new resistance genes have great importance for the development of new resistant cultivars. According to Lucinda et al. (2012), PepYMV resistant cultivars are mandatory in some regions of Brazil because of an intense occurrence of such virus. When evaluating 127 accessions of Capsicum spp for resistance to PepYMV, Bento et al. (2009) identified nine resistant genotypes, two of them from C. baccatum var. pendulum and seven of C. chinense.

Given the current world stage where a paradoxical search for healthier diets together with an unrestrained use of pesticides to control crop diseases, new pepper cultivars with multiple resistance to bacterial spot, anthracnosis, and PepYMV become such a contribution for farmers, consumers and seed traders since it may reduce production costs as well as increase crop environmental sustainability.

Therefore, this study aimed to identify genotypes with multiple resistance to BS, anthracnose, and PepYMV, which will be useful for breeding programs on peppers of the genus Capsicum spp aiming to farm sustainability.

\section{MATERIAL AND METHODS}

\section{Genotypes}

Fifty-four genotypes were evaluated, comprising 39 accessions from the UENF germplasm collection, nine experimental hybrids of $C$. baccatum var. pendulum, and six Capsicum cultivars (Table 1). These genotypes belong to four species of Capsicum, being 12 belonging to $C$. annuиm var. annuum, one of $C$. annuum var. glabriusculum, nine of $C$. chinense, eight of $C$. frutescens, and 22 genotypes of C. baccatum var. pendulum.

When assessing the resistance to BS, accession UENF 1381 (Costa et al., 2002; RivaSouza et al., 2007) was used as a resistance standard, and Jalapeño M as a susceptible cultivar (control) (Pimenta et al., 2016). For resistance to anthracnose, we only used the susceptible cultivar, 'Ikeda', as a control since there are no C. gloeosporioides resistant genotypes (Diao et al., 2017). For resistance to PepYMV, Criollo de Morelos 334 (CM-334) was used as a resistance standard (Nogueira et al., 2012), and 'Ikeda' as a susceptible standard.

\section{Crop conditions}

Two experiments were carried out. One of them evaluated the resistance to BS and

Genetics and Molecular Research 16 (3): gmr16039789 
to anthracnose (EXP1.1 and EXP1.2). Another evaluation was performed for resistance to PepYMV (EXP2). EXP1.1 and EXP1.2 was conducted in a greenhouse at Centro Estadual de Pesquisa em Agroenergia e Aproveitamento de Resíduos. EXP2 was carried out in cages coated with anti-aphid cloth bags, which were kept in a greenhouse at the Research Support Unit of the Universidade Estadual do Norte Fluminense Darcy Ribeiro (UENF). Both experimental fields are located in the city of Campos dos Goytacazes, RJ, Brazil.

\begin{tabular}{|c|c|c|c|c|c|}
\hline $\begin{array}{c}\text { Genotypes } \\
\end{array}$ & Species & Origen & Genotypes & Species & Origen \\
\hline $\begin{array}{ll}\text { Criollo de Morellos' }^{1} \\
\end{array}$ & \begin{tabular}{|l|} 
C. anmuum \\
\end{tabular} & & \begin{tabular}{|l|l|} 
UENF $1775^{1}$ \\
\end{tabular} & $\begin{array}{l}\text { C. frutescens } \\
\end{array}$ & \begin{tabular}{|l} 
Bequimão, MA \\
R
\end{tabular} \\
\hline $\begin{array}{ll}\text { Ilkeda }{ }^{2} \\
\text { UNFF } 1381^{1}\end{array}$ & \begin{tabular}{|l|} 
C. annuum var. annuum \\
C. annum var, annuum
\end{tabular} & \begin{tabular}{|l} 
Porto Alegre \\
PESAGRO
\end{tabular} & \begin{tabular}{|l|} 
UENF $1776^{1}$ \\
UENF $179^{1}$
\end{tabular} & $\begin{array}{l}\text { C. frutescens } \\
\text { C. frutescens }\end{array}$ & \begin{tabular}{|l|} 
Rosário, MA \\
Bequimâ, MA \\
\end{tabular} \\
\hline UENF $1622^{1}$ & C. annumim var. annumum & \begin{tabular}{|l} 
Estados Unidos \\
\end{tabular} & \begin{tabular}{|l|l|l|} 
UENF $1790^{1}$ \\
\end{tabular} & $\begin{array}{l}\text { C. Ifrutescens } \\
\text { C. frutens }\end{array}$ & \begin{tabular}{|l} 
São Luiz, MA \\
\end{tabular} \\
\hline UENF $1623^{1}$ & C. annuum var. annuum & \begin{tabular}{|l|} 
Campos, RJ \\
\end{tabular} & UENF $1800^{1}$ & C. frutescens & Bequimão, MA \\
\hline $\begin{array}{ll}\text { UENF } 1626^{1} \\
\text { UNDF } 167^{1}\end{array}$ & \begin{tabular}{|l} 
C. annuum var. annuum \\
\end{tabular} & Campos, RJ & \begin{tabular}{|l|l|} 
UENF $1490^{1}$ \\
\end{tabular} & C. baccatum var. pendulum & \begin{tabular}{|l|l|} 
Coleta - RJ \\
\end{tabular} \\
\hline $\begin{array}{ll}\text { UENF } 16277^{1} \\
\text { UNFF 1771 }\end{array}$ & 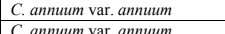 & \begin{tabular}{|l|} 
Campos, RJ \\
Renascenca. PR \\
\end{tabular} & \begin{tabular}{|l|} 
UENF $1616^{4}$ \\
UENF $164^{4}$
\end{tabular} & \begin{tabular}{|l|l} 
C. baccatum var. pendulum \\
\end{tabular} & \begin{tabular}{|l|l} 
Viçosa, MG \\
Compos BI
\end{tabular} \\
\hline$\frac{\text { UEEF } 17771^{1}}{\text { UENF } 1740^{1}}$ & \begin{tabular}{|l|} 
C. annumu var. annumum \\
C. annum var. annuum \\
\end{tabular} & \begin{tabular}{|l|} 
Renasscença, PR \\
Cachoiro de Macacu, RJ \\
\end{tabular} & \begin{tabular}{|l|} 
UENF $1622^{4}$ \\
UENF $1268^{1}$
\end{tabular} & \begin{tabular}{|l|} 
C. baccatum var. pendulum $m$ \\
C. bacacatum var pendulum
\end{tabular} & \begin{tabular}{|l|l|} 
Campos, RJ \\
Campos RJ
\end{tabular} \\
\hline UENF $1741^{1}$ & C. annuиm var. annum & Porto Alegre, RS & \begin{tabular}{|l|l|l|l|l|l} 
UENF $1629^{4}$ \\
\end{tabular} & 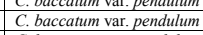 & \begin{tabular}{|l|} 
Camposs, $\mathrm{RJ}$ \\
RJ \\
\end{tabular} \\
\hline "UENF Carioca" ${ }^{33}$ & C. annuum var. annuum & Campos, RJ & UENF $1635^{1}$ & C. baccatum var. pendulum & Miranda, MS \\
\hline 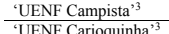 & 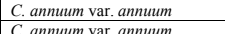 & \begin{tabular}{|l|} 
Campos, RJ \\
Compos RI
\end{tabular} & \begin{tabular}{|l|} 
UENF $1639^{4}$ \\
\end{tabular} & \begin{tabular}{|l|l} 
C. baccatum var. pendulum \\
\end{tabular} & \begin{tabular}{|l|l} 
Manhuaçu, MG \\
Dequ
\end{tabular} \\
\hline 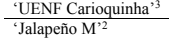 & 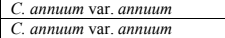 & \begin{tabular}{|l|} 
Campos, RJ \\
Săo Paulo, SP \\
\end{tabular} & \begin{tabular}{|l|} 
UENF $1714^{1}$ \\
UENF $1718^{1}$
\end{tabular} & \begin{tabular}{|l|} 
C. baccatum var. pendulum $m$ \\
C. bacacatum var pendulum
\end{tabular} & \begin{tabular}{|l|} 
Peru \\
Repascenca PR \\
\end{tabular} \\
\hline UENF $1750^{1}$ & C. annum var. glabriusculum & \begin{tabular}{|l} 
Salo aumpos, RJ \\
\end{tabular} & \begin{tabular}{|l} 
UENF 1718 \\
UENF $1732^{4}$ \\
\end{tabular} & \begin{tabular}{|l} 
C. baccacatum var. pendulumm \\
C. baccatum var. pendulum
\end{tabular} & \begin{tabular}{|l} 
Renascencac, , PR \\
Campos, $\mathrm{JJ}$ \\
\end{tabular} \\
\hline $\begin{array}{l}\text { UENF 1554' } \\
\end{array}$ & C. chinense & Goiânia, GO & UENF $1733^{1}$ & C. baccatum var. pendulum & Campos, RJ \\
\hline $\begin{array}{ll}\text { UENF } 1703^{1} \\
\end{array}$ & C. chinense & Viçosa, MG & UENF $1737^{1}$ & C. baccatum var. pendulum & Cachoeiro de Macacu, RJ \\
\hline$\frac{\text { UENN } 1706^{1}}{\text { UUNF } 1751^{1}}$ & $\begin{array}{l}\text { C. chinense } \\
\text { C chiverse } \\
\end{array}$ & \begin{tabular}{|l|} 
Viçosa, MG \\
Parituins AM
\end{tabular} & \begin{tabular}{|l|} 
UENF $1797^{1}$ \\
$S_{5}^{5}$
\end{tabular} & \begin{tabular}{|l|l} 
C. baccatum var. pendulum \\
\end{tabular} & Viçosa, MG \\
\hline$\frac{\text { UEEF } 1751^{1}}{\text { UENF } 1764^{1}}$ & \begin{tabular}{|l|l|l} 
C. chinense \\
. chinense
\end{tabular} & \begin{tabular}{|l} 
Parintins, AM \\
Belé, PA
\end{tabular} & \begin{tabular}{|l|}
$\mathrm{H}_{1}{ }^{5}$ \\
$\mathrm{H}_{2}$
\end{tabular} & \begin{tabular}{|l} 
C. baccactum var. pendulumm \\
C. baccatum var. pendulum
\end{tabular} & $\begin{array}{l}\text { Campos } \mathrm{RJ} \\
\text { Camps, RJ } \\
\end{array}$ \\
\hline $\begin{array}{l}\text { UENF } 1770^{1} \\
\end{array}$ & C. chinense & Belém, PA & $\mathrm{H}_{3} 3^{5}$ & C. baccatum var. pendulum & Campos, RJ \\
\hline UENF $1772^{1}$ & C. chinense & Bequimão, MA & \begin{tabular}{|l|l}
$4^{5}$ \\
$5^{5}$
\end{tabular} & C. baccatum var. pendulum & Campos, RJ \\
\hline $\begin{array}{ll}\text { UENF } 1780^{1} \\
\end{array}$ & $\begin{array}{l}\text { C. chinense } \\
\text { S chinser }\end{array}$ & Bequimão, MA & \begin{tabular}{|l|l}
$5^{5}$ \\
$5^{5}$
\end{tabular} & \begin{tabular}{|l|} 
C. baccatum var. pendulum \\
\end{tabular} & Campos, RJ \\
\hline$\frac{\text { UENF } 1798^{1}}{\text { UENF } 1731^{1}}$ & $\begin{array}{l}\text { C. chinense } \\
\text { C frutescens } \\
\end{array}$ & \begin{tabular}{|l|} 
Campos, RJ \\
Petrolina PE \\
\end{tabular} & \begin{tabular}{|l|l}
$6^{3}$ \\
$\mathrm{H}^{5}$
\end{tabular} & \begin{tabular}{|l|} 
C. . baccatum var. pendulum $m$ \\
C bacatum var pendlum
\end{tabular} & \begin{tabular}{|l|l|l} 
Campos, $\mathrm{RJ}$ \\
Campos $\mathrm{RJ}$
\end{tabular} \\
\hline UENF $1747^{1}$ & $\begin{array}{l}\text {. prusescins } \\
\text { C. frutescens } \\
\end{array}$ & Marajo-Soure, PA & \begin{tabular}{|l|l}
$\mathrm{H} \mathrm{s}^{5}$ \\
\end{tabular} & \begin{tabular}{|l|} 
C. baccacatum var. pentanum \\
\end{tabular} & \begin{tabular}{|l} 
Campos, RJ \\
\end{tabular} \\
\hline UENF $1766^{1}$ & C. frutescens & Belém, PA & $\mathrm{H}_{9^{5}}$ & C. baccatum var. pendulum & Campos, RJ \\
\hline
\end{tabular}

${ }^{1}$ Accessions belonging to the BAG/Capsicum/UENF; ${ }^{2}$ commercial witnesses; ${ }^{3}$ new cultivars developed by UENF; ${ }^{4}$ inbred lines, and ${ }^{5}$ experimental hybrid.

In both experiments, seeds were sown on 128-cell polystyrene trays, using a commercial substrate $\left(\right.$ Vivato $\left.^{\circledR}\right)$, remaining in a growing chamber kept at $28^{\circ} \mathrm{C}$ and a $12-\mathrm{h}$ photoperiod. After reaching four to six true leaves, seedlings were transplanted individually to 5-L pots (EXP1) and 500-mL plastic cups (EXP2), containing a mixture of soil and commercial substrate at a 2:1 ratio.

\section{EXP1.1 - Resistance assessment to BS}

The genotypes were distributed in a completely randomized design (CRD), with three replicates, to evaluate BS resistance. For this, two concentrations of bacterial suspension were used. The first contained $1.0 \times 10^{8} \mathrm{CFU} / \mathrm{mL}$, being in a hypersensitivity reaction (HR); the second, with $1.0 \times 10^{5} \mathrm{CFU} / \mathrm{mL}$, was used in a quantitative resistance evaluation. As inoculum, we used an ENA 4135 isolate, which was previously characterized as $X$. euvesicatoria by Riva-Souza et al. (2007), as classification proposed by Jones et al. (2004) and reported by Potnis et al. (2015). Both concentrations were inoculated on the same day in two distinct leaves of the same plant, duly identified.

The isolate was preserved in water stocks and recovered by transferring the bacterial suspension to Petri dishes containing DYGS medium (Rodrigues Neto et al., 1986), with a platinum loop. After incubation for $36 \mathrm{~h}$ at $28^{\circ} \mathrm{C}$, bacterial colonies were suspended in

Genetics and Molecular Research 16 (3): gmr16039789 
distilled and autoclaved water, and concentration was adjusted to $1.0 \times 10^{8} \mathrm{CFU} / \mathrm{mL}$ using a spectrophotometer $\left(\mathrm{A}_{600}=0.3\right)$ (Jones et al., 2000). Starting from this concentration, a serial dilution was performed to reach a concentration of $1.0 \times 10^{5} \mathrm{CFU} / \mathrm{mL}$.

Plants were inoculated 15 days after being transplanted by infiltration of bacterial suspension onto the leaf abaxial surface throughout an area of nearly $1.0 \mathrm{~cm}^{2}$, using a syringe and hypodermic needles (Riva-Souza et al., 2007; Pimenta et al., 2016).

HR was assessed 24 and $48 \mathrm{~h}$ after inoculation; evaluations consisted of presence (1) and absence (0) of local necrosis on the inoculated leaves. For quantitative resistance, evaluations started when the first symptoms were detected, in this case, on the fifth day after inoculation, lasting for nine days and occurring daily at the same time. To do so, scores from 1 to 5 were given according to the scoring range proposed by Riva-Souza et al. (2009). Scores from 1 to 2 were assigned as resistant genotypes, and from 3 to 5 as susceptible, so that the higher the score, the greater the susceptibility to the disease. Afterward, we estimated the area under the disease progress curve (AUDPC), as defined by Campbell and Madden (1990), and the incubation period (IP), which consists of the elapsed days between inoculation and the appearance of the first symptoms. After resistance evaluation, all the plants were grown until reproductive stage for further inoculation of $C$. gloeosporioides on immature and mature fruit.

\section{EXP1.2 - Resistance assessment to anthracnose}

For anthracnose, isolate from C. gloeosporioides was used, being previously tested, and identified as isolate \#8.1. It was inoculated into three fully developed fruits, detached from the same plant (replicates), at both immature (IF) and mature (MF) stages, totaling 972 evaluated fruits.

The isolate was cultured on PDA medium (potato-dextrose-agar) and then incubated in a BOD at $28^{\circ} \mathrm{C}$, under a 12 -h photoperiod, for seven days. A conidial suspension was prepared in deionized water, sterilized, and adjusted to a concentration of about $1.0 \times 10^{6}$ conidia/ $\mathrm{mL}$ in a Neubauer chamber, using an optical microscope.

Fruits were removed from the plants and transferred to the laboratory, being properly identified by genotype. After, they were sanitized by dipping them in a $70 \%$ alcohol solution for $1 \mathrm{~min}$ and then in a sodium hypochlorite solution $(0.2 \%)$ for $5 \mathrm{~min}$, after stalk removal. Later, they were three-time washed in sterile deionized water and dried with paper towel.

A conidial suspension $(10 \mu \mathrm{L})$ was dropped on each fruit; then, we used an entomological needle to wound the dropped area. After inoculation, the fruits were placed in a humid chamber at room temperature $\left( \pm 28^{\circ} \mathrm{C}\right)$. Evaluations were performed daily, at the same time, for seven days. Again, we made use of a scoring range, which was suggested by Montri et al. (2009) and used by Silva et al. (2014), thus determining the resistance levels on the seventh day of evaluation. Also, we calculated both incubation (IP) and latent (LP) periods of anthracnose infection, which correspond to the number of days between inoculation and the onset of symptoms, and between inoculation and the appearance of signs (acervulus formation), respectively.

\section{EXP2 - Resistance assessment to PepYMV}

In order to evaluate resistance to PepYMV, all 54 genotypes were distributed in a completely randomized design (DIC) with five replications, inside cages coated with antiaphid cloth bags.

Genetics and Molecular Research 16 (3): gmr16039789 
Plants of Nicotiana debneyi, infected with PepYMV isolate 3, were used as inoculum source (Truta et al., 2004). Professor Dr. Murilo Zerbini from the Laboratory of Plant Virology, Federal University of Viçosa, kindly provided both $N$. debneyi seeds and the viral isolate.

Inoculation was performed via plant extract buffered in $0.05 \mathrm{M}$ potassium phosphate, $\mathrm{pH} 7.2$, containing $0.01 \%$ sodium sulfate, and using 600 -mesh carborundum as abrasive (Truta et al., 2004). Plants were inoculated at the stage of 3 to 4 well-developed leaves, being reinoculated after $48 \mathrm{~h}$ to avoid escape. For all inoculations, we used young and fully expanded leaves.

Evaluations were made every two days from the 15th day after the first inoculation, which was when the symptoms began to appear. In this case, severity was assessed by score scale tested and validated by Bento et al. (2009), wherein: 1- absence of symptoms; 2- slight symptoms ( $25 \%$ leaf area with small mosaic areas); 3 - medium symptoms (50\% leaf area with mosaic); 4 - intense symptoms (75\% leaf area with mosaic), and 5 - severe symptoms (100\% leaf area with mosaic, blisters, leaf twisting and area reduction). After phenotyping, AUDPC and IP were estimated.

\section{Statistics}

The Lilliefors test was used to determine data normality. After, an individual analysis of variance (ANOVA) was performed. The means were grouped by the Scott-Knott test $(\mathrm{P}<$ 0.05), using the Genes software (Cruz, 2013).

For anthracnose, in particular, symptoms observed on the last day (seventh day) were classified according to Montri et al. (2009). In accordance with mean scores of symptom observed in each accession, we could rate them according to their level of resistance.

To avoid unsure resistance findings, based on a single variable, data underwent multivariate analysis for all tested variables, and for both BS and PepYMV. Thus, we made use of the algorithm of Gower (1971), thus obtaining the dissimilarity matrix among the genotypes. A simplified representation of genetic distances between genotypes was achieved by unweighted pair group method using arithmetic average (UPGMA) hierarchical grouping method. Matrices, distances, and the UPGMA grouping were performed using the R software package (http://www.r-project.org).

\section{RESULTS}

\section{EXP1.1 - Resistance assessment to BS}

The studied genotypes showed variability for resistance to BS. Seventeen of them were resistant according to the HR test (14 accessions of C. baccatum var. pendulum, two of $C$. frutescens, and one of $C$. annuиm var. annuиm), being hypersensitive to the pathogen.

We inoculated in the evaluated genotypes only one isolate of $X$. euvesicatoria (previously strain T1P3); however, a relatively high number of genotypes reacted (32\%).

The AUDPC for BS ranged between 8.0 and 35.8, averaging 23.43. Twenty genotypes were considered resistant to this disease, since the standard accession, UENF 1381, was grouped to another 19 genotypes by the Scott-Knott test (Table 2). Among them, eleven are $C$. baccatum var. pendulum, five are $C$. annuum var. annuum, one is $C$. annuum var. glabriusculum, and two are $C$. chinense. No accessions were solely resistant to $C$. frutescens when considering the AUDPC.

Genetics and Molecular Research 16 (3): gmr16039789 
Table 2. Clustering of averages by Scott Knott $(\mathrm{P}<0.05)$ of 54 genotypes of Capsicum spp relative to the variables (AUDPC), hypersensitivity reaction (HR) and incubation period (IP) of the bacterial spot and the yellow pepper mosaic. Campos dos Goytacazes, 2016.

\begin{tabular}{|c|c|c|c|c|c|c|c|c|c|c|c|}
\hline \multirow[t]{2}{*}{ Genotypes } & \multicolumn{3}{|c|}{ Bacterial } & \multicolumn{2}{|c|}{ Virus } & \multirow[t]{2}{*}{ Genotypes } & \multicolumn{3}{|c|}{ Bacterial } & \multicolumn{2}{|c|}{ Virus } \\
\hline & $\begin{array}{l}\text { AUDPC }^{1} \\
\text { Average }\end{array}$ & $\begin{array}{c}\text { IP } \\
\text { Average }\end{array}$ & HR & $\begin{array}{l}\text { AUDPC } \\
\text { Average }\end{array}$ & $\begin{array}{c}\text { IP } \\
\text { Average }\end{array}$ & & $\begin{array}{c}\text { AUPDPC } \\
\text { Average }\end{array}$ & $\begin{array}{c}\text { IP } \\
\text { Average }\end{array}$ & HR & $\begin{array}{l}\text { AUDPC } \\
\text { Average }\end{array}$ & $\begin{array}{c}\text { IP } \\
\text { Average }\end{array}$ \\
\hline UENF 1381 & $08.00 \mathrm{~b}$ & $15.00 \mathrm{a}$ & 0 & $25.20 \mathrm{c}$ & $27.40 \mathrm{~b}$ & \begin{tabular}{|l|} 
UENF 1766 \\
\end{tabular} & $27.00 \mathrm{a}$ & $08.00 \mathrm{~b}$ & 0 & $25.80 \mathrm{c}$ & $21.00 \mathrm{c}$ \\
\hline UENF 1490 & $08.50 \mathrm{~b}$ & $14.67 \mathrm{a}$ & 1 & $14.50 \mathrm{~d}$ & $34.20 \mathrm{a}$ & \begin{tabular}{|l|} 
UENF 1766 \\
\end{tabular} & $29.16 \mathrm{a}$ & $08.67 \mathrm{~b}$ & 0 & $44.70 \mathrm{~b}$ & $11.40 \mathrm{~d}$ \\
\hline UENF 1554 & $23.83 \mathrm{a}$ & $07.67 \mathrm{~b}$ & 0 & $24.40 \mathrm{c}$ & $25.80 \mathrm{~b}$ & \begin{tabular}{|l|} 
UENF 1770 \\
\end{tabular} & $17.60 \mathrm{~b}$ & $10.30 \mathrm{~b}$ & 0 & $14.00 \mathrm{~d}$ & $35.00 \mathrm{a}$ \\
\hline UENF 1616 & $28.00 \mathrm{a}$ & $07.32 \mathrm{~b}$ & 1 & $14.00 \mathrm{~d}$ & $35.00 \mathrm{a}$ & \begin{tabular}{|l} 
UENF 1772 \\
\end{tabular} & $34.60 \mathrm{a}$ & $07.67 \mathrm{~b}$ & 0 & NR & NR \\
\hline UENF 1622 & $21.50 \mathrm{a}$ & $10.00 \mathrm{~b}$ & 0 & NR & NR & \begin{tabular}{|l} 
UENF 1775 \\
\end{tabular} & $34.50 \mathrm{a}$ & $07.33 \mathrm{~b}$ & 0 & $47.40 \mathrm{a}$ & $16.20 \mathrm{c}$ \\
\hline UENF 1623 & $22.60 \mathrm{a}$ & $10.00 \mathrm{~b}$ & 1 & $52.00 \mathrm{a}$ & $11.00 \mathrm{~d}$ & UENF 1776 & $34.80 \mathrm{a}$ & $07.33 \mathrm{~b}$ & 0 & $44.60 \mathrm{~b}$ & $14.20 \mathrm{~d}$ \\
\hline UENF 1624 & $08.00 \mathrm{~b}$ & $15.00 \mathrm{a}$ & 1 & $14.00 \mathrm{~d}$ & $35.00 \mathrm{a}$ & \begin{tabular}{|l|} 
UENF 1779 \\
\end{tabular} & $35.80 \mathrm{a}$ & $07.33 \mathrm{~b}$ & $\frac{1}{1}$ & $54.00 \mathrm{a}$ & $11.00 \mathrm{~d}$ \\
\hline $\begin{array}{l}\text { UENF } 1626 \\
\end{array}$ & $16.60 \mathrm{~b}$ & $12.33 \mathrm{a}$ & 0 & $56.00 \mathrm{a}$ & $11.00 \mathrm{~d}$ & \begin{tabular}{|l|} 
UENF 1780 \\
\end{tabular} & $32.50 \mathrm{a}$ & $07.67 \mathrm{~b}$ & 0 & $37.40 \mathrm{~b}$ & $21.00 \mathrm{c}$ \\
\hline $\begin{array}{l}\text { UENF } 1627 \\
\end{array}$ & $22.00 \mathrm{a}$ & $09.00 \mathrm{~b}$ & 0 & $57.40 \mathrm{a}$ & $11.00 \mathrm{~d}$ & UENF 1790 & $32.83 \mathrm{a}$ & $08.00 \mathrm{~b}$ & 0 & $48.90 \mathrm{a}$ & $11.40 \mathrm{~d}$ \\
\hline UENF 1628 & $26.30 \mathrm{a}$ & $10.00 \mathrm{~b}$ & 0 & $46.80 \mathrm{a}$ & $11.00 \mathrm{~d}$ & UENF 1797 & $27.50 \mathrm{a}$ & $07.67 \mathrm{~b}$ & 1 & $34.40 \mathrm{~b}$ & $13.80 \mathrm{~d}$ \\
\hline $\begin{array}{l}\text { UENNF } 1628 \\
\text { UENF }\end{array}$ & $20.30 \mathrm{~d}$ & $\frac{10.00 \mathrm{D}}{15.00 \mathrm{a}}$ & 0 & $\begin{array}{l}40.80 \mathrm{a} \\
47.04 \mathrm{a}\end{array}$ & $11.00 \mathrm{~d}$ & \begin{tabular}{|l} 
UENF 1798 \\
\end{tabular} & $28.00 \mathrm{a}$ & $08.00 \mathrm{~b}$ & $\frac{1}{0}$ & $\frac{34.40 \mathrm{D}}{26.50 \mathrm{c}}$ & $11.00 \mathrm{~d}$ \\
\hline UENF 1635 & $17.50 \mathrm{~b}$ & $12.33 \mathrm{a}$ & 0 & $57.20 \mathrm{a}$ & $11.00 \mathrm{~d}$ & UENF 1800 & $34.60 \mathrm{a}$ & $07.33 \mathrm{~b}$ & 0 & $54.00 \mathrm{a}$ & $11.00 \mathrm{~d}$ \\
\hline UENF 1639 & $09.50 \mathrm{~b}$ & $13.67 \mathrm{a}$ & 0 & $48.00 \mathrm{a}$ & $11.00 \mathrm{~d}$ & $\begin{array}{ll}\mathrm{H} 2 \\
\end{array}$ & $23.60 \mathrm{a}$ & $07.33 \mathrm{~b}$ & 0 & $26.70 \mathrm{c}$ & $15.40 \mathrm{c}$ \\
\hline UENF 1703 & $12.00 \mathrm{~b}$ & $11.30 \mathrm{a}$ & 0 & $14.00 \mathrm{~d}$ & $35.00 \mathrm{a}$ & $\mathrm{H} 3$ & $32.16 \mathrm{a}$ & $07.00 \mathrm{~b}$ & 1 & $37.30 \mathrm{~b}$ & $11.00 \mathrm{~d}$ \\
\hline UENF 1706 & $34.80 \mathrm{a}$ & $07.67 \mathrm{~b}$ & 0 & $14.00 \mathrm{~d}$ & $35.00 \mathrm{a}$ & $\mathrm{H} 4$ & $20.46 \mathrm{~b}$ & $10.00 \mathrm{~b}$ & 1 & $14.00 \mathrm{~d}$ & $35.00 \mathrm{a}$ \\
\hline UENF 1714 & $\frac{34.80 \mathrm{a}}{30.10 \mathrm{a}}$ & $08.33 \mathrm{~b}$ & $\frac{0}{1}$ & $14.00 \mathrm{~d}$ & $35.00 \mathrm{a}$ & \begin{tabular}{|l|}
14 \\
$\mathrm{H} 5$ \\
\end{tabular} & $\frac{20.40 \mathrm{~b}}{19.00 \mathrm{~b}}$ & $10.00 \mathrm{~b}$ & $\frac{1}{1}$ & $\frac{14.00 \mathrm{c}}{22.30 \mathrm{c}}$ & $20.20 \mathrm{c}$ \\
\hline UENF 1717 & $33.60 \mathrm{a}$ & $07.33 \mathrm{~b}$ & 0 & $54.20 \mathrm{a}$ & $11.00 \mathrm{~d}$ & \begin{tabular}{|l|l}
$\mathrm{H} 6$ \\
\end{tabular} & $30.60 \mathrm{a}$ & $09.50 \mathrm{~b}$ & 1 & $15.70 \mathrm{~d}$ & $31.80 \mathrm{a}$ \\
\hline UENF 1718 & $15.10 \mathrm{~b}$ & $10.30 \mathrm{~b}$ & 1 & $44.00 \mathrm{~b}$ & $11.80 \mathrm{~d}$ & \begin{tabular}{|l|l}
$\mathrm{H} 7$ \\
\end{tabular} & $14.75 \mathrm{~b}$ & $11.67 \mathrm{a}$ & 0 & $14.50 \mathrm{~d}$ & $34.33 \mathrm{a}$ \\
\hline UENF 1731 & $34.16 \mathrm{a}$ & $07.33 \mathrm{~b}$ & 1 & $45.30 \mathrm{~b}$ & $11.80 \mathrm{~d}$ & H8 & $14.16 \mathrm{~b}$ & $11.00 \mathrm{a}$ & 0 & $41.70 \mathrm{a}$ & $11.00 \mathrm{~d}$ \\
\hline UENF 1732 & $30.60 \mathrm{a}$ & $07.33 \mathrm{~b}$ & 0 & $15.10 \mathrm{~d}$ & $33.80 \mathrm{a}$ & $\mathrm{H} 9$ & $15.16 \mathrm{~b}$ & $07.33 \mathrm{~b}$ & 1 & $27.20 \mathrm{c}$ & $18.20 \mathrm{c}$ \\
\hline UENF 1733 & $35.00 \mathrm{a}$ & $07.33 \mathrm{~b}$ & $\frac{0}{1}$ & $14.00 \mathrm{~d}$ & $35.00 \mathrm{a}$ & \begin{tabular}{|l|}
$\mathrm{H} 10$ \\
\end{tabular} & $\frac{15.10 \mathrm{v}}{28.60 \mathrm{a}}$ & $09.00 \mathrm{~b}$ & $\frac{1}{1}$ & $36.30 \mathrm{~b}$ & $11.40 \mathrm{~d}$ \\
\hline UENF 1737 & $33.10 \mathrm{a}$ & $07.33 \mathrm{~b}$ & 1 & $14.00 \mathrm{~d}$ & $35.00 \mathrm{a}$ & "Criolo de Morellos' & $20.50 \mathrm{~b}$ & $09.67 \mathrm{~b}$ & 0 & $14.00 \mathrm{~d}$ & $35.00 \mathrm{a}$ \\
\hline UENF 1740 & $23.50 \mathrm{a}$ & $08.00 \mathrm{~b}$ & 0 & $47.80 \mathrm{a}$ & $16.20 \mathrm{c}$ & 'UENF Campista' & $08.00 \mathrm{~b}$ & $15.00 \mathrm{~b}$ & 0 & $27.00 \mathrm{c}$ & $21.80 \mathrm{c}$ \\
\hline UENF 1741 & $32.30 \mathrm{a}$ & $07.33 \mathrm{~b}$ & 0 & $53.40 \mathrm{a}$ & $11.00 \mathrm{~d}$ & 'UENF Carioquinha' & $08.00 \mathrm{~b}$ & $15.00 \mathrm{~b}$ & 0 & $37.40 \mathrm{~b}$ & $16.20 \mathrm{c}$ \\
\hline UENF 1747 & $35.16 \mathrm{a}$ & $07.33 \mathrm{~b}$ & 0 & $49.60 \mathrm{a}$ & $11.80 \mathrm{~d}$ & 'UENF Carioca' & $08.00 \mathrm{~b}$ & $15.00 \mathrm{~b}$ & 0 & $30.60 \mathrm{c}$ & $21.80 \mathrm{c}$ \\
\hline UENF 1750 & $08.00 \mathrm{~b}$ & $15.00 \mathrm{a}$ & 0 & $29.40 \mathrm{c}$ & $25.40 \mathrm{~b}$ & \begin{tabular}{|l} 
'Jalapeño M' \\
\end{tabular} & $24.33 \mathrm{a}$ & $07.00 \mathrm{~b}$ & 0 & $19.40 \mathrm{~d}$ & $31.00 \mathrm{a}$ \\
\hline UENF 1751 & $30.30 \mathrm{a}$ & $08.00 \mathrm{~b}$ & 0 & $14.00 \mathrm{~d}$ & $35.00 \mathrm{a}$ & \begin{tabular}{|l|} 
"IKEDA' \\
\end{tabular} & NR & NR & $\mathrm{NR}$ & $43.00 \mathrm{~b}$ & $14.20 \mathrm{~d}$ \\
\hline
\end{tabular}

${ }^{1} \mathrm{AUDPC}=$ area under the disease progress; $\mathrm{IP}=$ incubation period; $\mathrm{NR}=$ not rated.

BS IP varied from seven to 15 days, with an average of 10 days. Fourteen genotypes were within the same group with the highest IP values, i.e., at or above 11 days. These genotypes include all species studied here, except for $C$. frutescens, likewise the results observed for AUDPC (Table 2). The experimental hybrids H6 and H7 were resistant to BS and, despite not having any relationship (same parent), they have agronomic characteristics required by consumer market (Gonçalves et al., 2011; Bento et al., 2016) and were deemed promising to be released to farmers after cropping values tests. Genotype UENF 1750 (C. annuum var. glabriusculum) had the lowest value for AUDPC (8.00) and higher value for IP (15).

\section{EXP1.2 - Resistance assessment to anthracnose}

Only accession UENF 1381 was classified as resistant to anthracnose, for immature fruit, based on the scale of Montri et al. (2009), on the 17th day. The others were susceptible at different levels, among which three were moderately susceptible, four susceptible and 46 highly susceptible. For mature fruit, there were no resistance genotypes; however, 16 of them were moderately resistant, including UENF 1381. It was required an IP of three days for immature fruit, and four days for mature ones. Regarding LP, immature fruits needed six days and eight days for mature ones. Accession UENF1381 had the highest value for IP and LP for immature fruit, without any symptom, considering eight days. For mature fruit, this accession showed a five-day IP and an eight-day LP, that is, presented symptoms but did not produce any signs.

\section{EXP2 - Resistance assessment to PepYMV}

Regarding PepYMV, AUDPC and IP for the virus ranged from 14 to 57.4 and from 11 to 35 days, respectively. Considering both of them, we verified resistance in 16 genotypes, four of which were for C. chinense, ten for C. baccatum var. pendulum, and two for C. annuum var. 
annuum (Table 2). The hybrids of C. baccatum, H5, and H6, were considered promising because they obtained two desirable resistance components to PepYMV, which were AUDPC and IP.

\section{Multivariate analysis}

Based on the multivariate analysis, six groups were identified in the UPGMA dendrogram at a dissimilarity level of 0.30 , with distinct resistance traits. The first group was characterized as being intermediate for resistance to BS, with no HR and being highly resistant to PepYMV. This group consisted of four accessions, including the virus resistance standard 'Criollo de Morelos' (Figure 1).

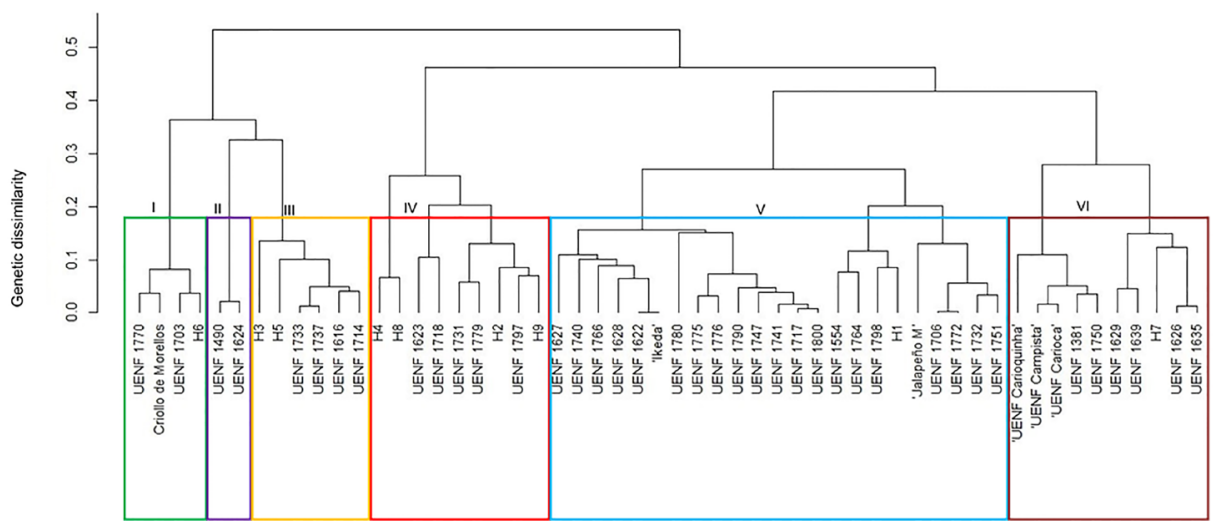

Figure 1. Dendrogram obtained by the UPGMA method for the variables below area under the disease progress curve (AUDPC), hypersensitivity reaction (HR) and incubation period (IP) of bacterial spot and yellow pepper mosaic. Campos dos Goytacazes, 2016.

The second group was highly resistant to both BS and to the virus, showing highly favorable results for all evaluated resistance variables. This group consisted of two accessions of C. baccatum var. pendulum (UENF 1490 and UENF 1624). Group III was formed only by genotypes of $C$. baccatum var. pendulum, which was susceptible to quantitative resistance to BS; however, all of them showed hypersensitivity reaction to the bacterium and were highly resistant to PepYMV.

The fourth and fifth groups included nine and 23 genotypes, respectively. These groups were susceptible to BS, for quantitative resistance, and to PepYMV. However, they differed regarding HR, and only the fourth group showed genotypes with such resistance. The sixth and last group consisted of ten genotypes resembling each other, once they had only quantitative resistance to BS, that is, without HR expression and being moderately susceptible to PepYMV. Accession UENF 1381 was allocated to this last group, which is the resistance standard to BS, besides three cultivars derived from this accession.

\section{DISCUSSION}

\section{EXP1.1 - Resistance assessment to BS}

The variability found for the hypersensitivity reaction is important and may contribute

Genetics and Molecular Research 16 (3): gmr16039789 
to the breeding of new commercial genotypes of both sweet and chili peppers. Plant hypersensitivity to a particular pathogen can narrow and eventually kill it, thus contributing to the disease control (Kombrink and Schmelzer, 2001; Wai et al., 2015).

However, HR is considered provisional since the longevity of a BS resistance gene depends on the stability of pathogen's avr gene. Nevertheless, combining several HR genes into the same cultivar can confer a prolonged resistance (Stall et al., 2009).

Following the gene-to-gene hypothesis proposed by Flor (1955), three non-allelic and dominant genes ( $B s 1, B s 2$, and $B s 3)$ might have conferred resistance to BS, being expressed phenotypically by means of HR (Hibberd et al., 1987). Nonetheless, other interactive genes with avirulence alleles ( $a v r B s T$, avrBs $4 C$ and $a v r B s 7$ ) have been described in bacterial isolates, promoting HR. As examples, we may cite $B s T$ (Minsavage et al., 1990), Bs $4 C$ (Straub et al., 2012), and Bs7 (Potnis et al., 2012).

One-third of the genotypes showed a hypersensitivity reaction to a single isolated $X$. euvesicatoria (T1P3). This result leads us to assume that more than one allele might be responsible for these phenotypes; and, for race 3, two resistance genes (Bs2 and $B s 4)$ are associated to resistance in the same plant. Thus, it is feasible to use multilines for these genotypes, which serves as a strategy to increase resistance stability (Stall et al., 2009).

By the results obtained for the AUDPC-BS six genotypes of C. annuum were resistant, one is the resistance pattern (UENF 1381), as already expected, three genotypes ('UENF Campista', 'UENF Carioquinha', and 'UENF Carioca') were resistant since they are cultivars developed from crosses involving UENF 1381 (Riva-Souza et al., 2007, 2009; Pimenta et al., 2016). Three recessive genes confer genetic control of BS resistance (Riva et al., 2004b); therefore, the studied cultivars are homozygous for this trait.

Genotype UENF 1750 (C. annuum var. glabriusculum) had relatively low values for AUDPC and high for IP. Such observation is important because this genotype is little exploited commercially and can be used in breeding programs for new cultivars; since to date, there is no record in Brazil of any commercial cultivar of this species (Brasil, 2015). In Mexico, consumers who pay high prices considered one variety of $C$. annuum var. glabriusculum as 'premium'. This preference is mainly due to its better flavor whether compared to the other types of peppers such as Serrano and Jalapeño (Villalon-Mendoza et al., 2014).

\section{EXP1.2 - Resistance assessment to anthracnose}

In relation to anthracnose, only one genotype (UENF 1381) in immature fruit was resistant and the others were classified as susceptible in different degrees of aggressiveness, and in the mature fruit this genotype was moderately resistant as well as a further 15 genotypes and the rest susceptible. These results demonstrate the ongoing aggressiveness of isolate \#8.1, as well as UENF 1381 accession resistance.

The genetic control of anthracnose resistance is considered complex because it varies according to Colletotrichum species, isolate, and host species (Ying et al., 2015). In Capsicum genus, resistance control depends on the plant organ under study, such as leaf or fruit (Mahasuk et al., 2009a). In the case of fruit, resistance may also vary with maturation stage, whether immature or mature (Silva et al., 2014; Sun et al., 2015; Suwor et al., 2015). In this study, we noticed that immature fruit was more susceptible to anthracnose than mature ones, which corroborates the hypothesis of different genetic control in these maturation stages.

The Asian Vegetable Research Development Center (AVRDC) identified, in 1997 and

Genetics and Molecular Research 16 (3): gmr16039789 
in 1999, the main sources of anthracnose resistance in Capsicum plants for C. baccatum and C. chinense (Pakdeevaraporn et al., 2005). Since then, several researchers have used these genotypes in Capsicum breeding programs for resistance to anthracnose. As examples, we may cite studies developed by Pakdeevaraporn et al. (2005) and Mahasuk et al. (2009a), who crossed PBC932 (C. chinense) with 'Bangchang' (C. annuum). These authors noted that resistance was controlled by one gene (co1) in green fruit, by another ( $\mathrm{co} 2)$ red fruit, and yet another (co3) in seedlings, when using a $C$. capsici isolate identified as ' $158 \mathrm{ci}$ '. In addition, Mahasuk et al. (2009b) evaluated C. baccatum progenies from PBC80 x PBC1422 crossing, comprising 13 isolates of $C$. capsici and $C$. acutatum, found two new genes: $c 04$ (controlling resistance in green fruit) and $\operatorname{Co5}$ (controlling resistance in red fruit). The genetic control of anthracnose resistance for accession UENF 1381 has not yet been identified, therefore, determining it may contribute to the development of new resistant cultivars and to the better understanding of plant-pathogen interaction.

\section{EXP2 - Resistance assessment to PepYMV}

PepYMV resistance sources in some species of Capsicum have already been reported, such as for C. annuum, cultivars 'Perennial' and 'Magali R' (Truta et al., 2004; Nascimento et al., 2007), two accessions of $C$. baccatum var. pendulum, seven species of $C$. chinense (Bento et al., 2009), and cultivar 'BRS Juruti' (C. chinense) (Ribeiro et al., 2015), among others. However, few papers have cited multiple resistance including PepYMV, one of the few examples is the study of Nascimento et al. (2007). In this research, these authors evaluated $C$. annuum strains, cultivars, and hybrids for resistance to Phytophthora capsici and to PepYMV; they found resistance to both pathogens in two progenies, and one hybrid of C. annuum.

\section{Multivariate analysis}

By the UPGMA method the first group was highlighted as being highly resistant to PepYMV, including the resistance pattern. In this group the genotype UENF 1703 of $C$. chinense showed no hypersensitivity reaction, it was moderately resistant to bacterial spot, and could be considered a promising genotype for resistance source to develop new cultivars from $C$. chinense that are resistant to both BS and to PepYMV.

The two accessions of second group have already been characterized morphoagronomically and molecularly (Leite et al., 2016) and showed traits of interest for the pepper market such as productivity, intense red fruit color when mature, total soluble solids content near to $7.0^{\circ}$ Brix, among others (Bento et al., 2009; Assis, 2014; Leite et al., 2016). Assis (2014) assessed 30 genotypes of $C$. baccatum, including these two accessions, pointing out $100 \%$ antioxidant activity to UENF 1490 . Therefore, when we admit that promising accessions have not yet been studied, from a breeding standpoint, a mass selection can be applied to provide resistant strains with good agronomic characteristics. In addition, these accessions may also be recommended as parents of breeding programs, for resistance to both diseases.

\section{CONCLUSIONS}

Capsicum frutescens was most susceptible to the three diseases jointly. At least one genotype of C. baccatum, C. annuum, and C. chinense had a potential for use in breeding

Genetics and Molecular Research 16 (3): gmr16039789 
programs for resistance to bacterial spot and PepYMV. The genotypes UENF 1490 and UENF 1624 , both of $C$. baccatum var. pendulum, were highly resistant regarding all resistance variables to bacterial spot and PepYMV.

The genotype UENF 1381 (C. аnnuиm) was the only one presenting multiple resistance to the three pathogens, being highly resistant to bacterial spot and anthracnose in immature fruit, and moderately resistant to PepYMV and anthracnose in mature fruit. UENF 1381 is a promising genotype to be further used in breeding programs to disease resistance in Capsicum.

\section{ACKNOWLEDGMENTS}

Authors thank to Coordenação de Aperfeiçoamento de Pessoal de Nível Superiorl (CAPES) for scholarships awarded to the second and fourth authors and to Fundação Carlos Chagas Filho de Amparo à Pesquisa do Estado do Rio de Janeiro (FAPERJ) for scholarships awarded to the first author.

\section{REFERENCES}

Areas MS, Goncalves RM, Soman JM, Sakate RK, et al. (2015). Prevalence of Xanthomonas euvesicatoria on pepper in Brazil. J. Phytopathol. 163: 1050-1054. https://doi.org/10.1111/jph.12349

Assis MLV (2014). Determinação do potencial antioxidante e quantificação de compostos fenólicos por CLAE em acessos de Capsicum baccatum var. pendulum. Master's thesis, Universidade Estadual do Norte Fluminense Darcy Ribeiro, UENF, Campos dos Goytacazes.

Bento CS, Rodrigues R, Gonçalves LSA, Oliveira HS, et al. (2013). Inheritance of resistance to Pepper yellow mosaic virus in Capsicum baccatum var. pendulum. Genet. Mol. Res. 12: 1074-1082. https://doi.org/10.4238/2013.April.10.3

Bento CS, Rodrigues R, Zerbini Júnior FM and Sudré CP (2009). Sources of resistance against the Pepper yellow mosaic virus in chili pepper. Hortic. Bras. 27: 196-201. https://doi.org/10.1590/S0102-05362009000200013

Bento CS, Rodrigues R, Sudré CP, Medeiros AM, et al. (2016). Determining the inheritance of agronomic traits in chili pepper. Hortic. Bras. 34: 367-373. https://doi.org/10.1590/S0102-05362016003010

Brasil (2015). Ministério da Agricultura. SNPC - Sistema de Cultivar Web Available at [http://extranet.agricultura.gov.br/ $\mathrm{php} / \mathrm{snpc} /$ cultivarweb/cultivares_registradas.php].

Campbell CL and Madden LV (1990). Introduction to plant disease epidemiology. John Wiley \& Sons, New York.

Clark R and Lee SH (2016). Anticancer Properties of Capsaicin Against Human Cancer. Anticancer Res. 36: 837-843.

Costa RA, Rodrigues R and Sudré CP (2002). Resistência genética à mancha bacteriana em genótipos de pimentão. Hortic. Bras. 20: 86-89. https://doi.org/10.1590/S0102-05362002000100016

Cruz (2013). Programa Genes versão Windows. Aplicativo computacional em Genética e Estatística. Editora UFV, Viçosa.

Diao YZ, Zhang C, Liu F, Wang WZ, et al. (2017). Colletotrichum species causing anthracnose disease of chili in China. Pers.-Molec. Phylog. Evol. Fungi, 38: 20-37.

FAOSTAT Database results. Food and Agriculture Organization (FAO) of the United Nations, Rome, Italy. (2012). Available at [http://faostat3.fao.org/faostat-gateway/go/to/browse/Q/QC/E].

FAOSTAT Database results. Food and Agriculture Organization (FAO) of the United Nations, Rome, Italy. (2013). Available at [http://faostat3.fao.org/faostat-gateway/go/to/browse/Q/QC/E].

Flor HH (1955). Host-parasite interaction in flax rust-its genetics and other implications. Phytopathology 45: 680-685.

Gonçalves LSA, Rodrigues R, Bento CS, Robaina RR, et al. (2011). Herança de caracteres relacionados à produção de frutos em Capsicum baccatum var. pendulum com base em análise dialélica de Hayman. Rev. Cienc. Agron. 42: 662669. https://doi.org/10.1590/S1806-66902011000300012

Gower JC (1971). A General Coefficient of Similarity and Some of Its Properties. Biomet. 27:857-871.

Haddad F, Maffia LA and Mizubuti ESG (2003). Avaliação de fungicidas para o controle de Colletotrichum gloeosporioides em cebola. Fitopatol. Bras. 28: 435-437. https://doi.org/10.1590/S0100-41582003000400016

Hibberd AM, Bassett MJ and Stall RE (1987). Allelism tests of three dominant genes for hypersensitive resistance to bacterial spot of pepper. Phytopathology 77: 1304-1307. https://doi.org/10.1094/Phyto-77-1304

Holdsworth W L and Mazourek M (2015). Development of user-friendly markers for the pvr1 and Bs3 disease resistance genes in pepper. Molec. Breed. 35:1-5.

Genetics and Molecular Research 16 (3): gmr16039789 
Jones JB, Lacy GH, Bouzar H, Stall RE, et al. (2004). Reclassification of the xanthomonads associated with bacterial spot disease of tomato and pepper. Syst. Appl. Microbiol. 27: 755-762. https://doi.org/10.1078/0723202042369884

Jones JB, Bouzar H, Stall RE, Almira EC, et al. (2000). Systematic analysis of xanthomonads (Xanthomonas spp.) associated with pepper and tomato lesions. Int. J. Syst. Evol. Microbiol. 50: 1211-1219. https://doi.org/10.1099/00207713-50-3-1211

Jones JB, Stall RE and Bouzar H (1998). Diversity among xanthomonads pathogenic on pepper and tomato. Annu. Rev. Phytopathol. 36: 41-58. https://doi.org/10.1146/annurev.phyto.36.1.41

Kiss GB, Szabó Z, Illiescu CE and Balogh M (2016). U.S. Patent No. 20,160,138,041. Washington, DC: U.S. Patent and Trademark Office.

Kombrink E and Schmelzer E (2001). The hypersensitive response and its role in local and systemic disease resistance. Eur. J. Plant Pathol. 107: 69-78. https://doi.org/10.1023/A:1008736629717

Leite PS, Rodrigues R, Silva RN, Pimenta S, et al. (2016). Molecular and agronomic analysis of intraspecific variability in Capsicum baccatum var. pendulum accessions. Genet. Mol. Res. 15:1-16.

Lucinda N, da Rocha WB, Inoue-Nagata AK and Nagata T (2012). Complete genome sequence of pepper yellow mosaic virus, a potyvirus, occurring in Brazil. Arch. Virol. 157: 1397-1401. https://doi.org/10.1007/s00705-012-1313-z

Maciel-Zambolim E, Costa H, Capucho AS, Ávila AC, et al. (2004). Surto Epidemiológico do Vírus do Mosaico Amarelo do Pimentão em Tomateiro na Região Serrana do Espírito Santo. Fitopatol. Bras. 29: 325-327. https://doi. org $/ 10.1590 /$ S0100-41582004000300017

Mahasuk P, Khumpeng N, Wasee S, Taylor PWJ, et al. (2009a). Inheritance of resistance to anthracnose (Colletotrichum capsici) at seedling and fruiting stages in chili pepper (Capsicum spp.). Plant Breed. 128: 701-706.

Mahasuk P, Taylor PW, Mongkolporn O (2009b). Identification of two new genes conferring resistance to Colletotrichum acutatum in Capsicum baccatum. Phytopat. 99: 1100-1104.

Minsavage GV, Dahlbeck D, Whalen MC, Kearney B, et al. (1990). Gene-for-gene relationships specifying disease resistance in Xanthomonas campestris pv. vesicatoria pepper interactions. Mol. Plant Microbe Interact. 3: 41-47. https://doi.org/10.1094/MPMI-3-041

Montri P, Taylor PWJ and Mongkolporn O (2009). Pathotypes of Colletotrichum capsici, the Causal Agent of Chili Anthracnose, in Thailand. Plant Dis. 93: 17-20.

Moreira SO, Rodrigues R, Oliveira HS, Medeiros AM, et al. (2013). Phenotypic and genotypic variation among Capsicum annuum recombinant inbred lines resistant to bacterial spot. Genet. Mol. Res. 12: 1232-1242. https://doi. org/10.4238/2013.April.17.2

Nascimento ID, Valle LD, Maluf WR, Gonçalves LD, et al. (2007). Reação de híbridos, linhagens e progênies de pimentão à requeima causada por Phytophthora capsici e ao mosaico amarelo causado por Pepper yellow mosaic virus (PepYMV). Cienc. Agrotec. 31: 121-128. https://doi.org/10.1590/S1413-70542007000100018

Nogueira DW, Nogueira DG, Maluf WR, Maciel GM, et al. (2012). Seleção assistida com uso de marcador molecular para resistência a potyvírus em pimentão. Pesqui. Agropecu. Bras. 47: 955-963. https://doi.org/10.1590/S0100$\underline{204 X 2012000700012}$

Pakdeevaraporn P, Wasee S, Taylor PWJ and Mongkolporn O (2005). Inheritance of resistance to anthracnose caused by Colletotrichum capsici in Capsicum. Plant. Breed. 124: 206-208.

Parrella G, Ruffel S, Moretti A, Morel C, et al. (2002) Recessive resistance genes against potyviruses are localized in collinear genomic regions of the tomato (Lycopersicon spp.) and pepper (Capsicum spp.) genomes. Theor. Appl. Genet. 105: 855-861.

Pimenta S, Rodrigues R, Sudré C P, Moraes JG, et al. (2016). Protecting vegetable cultivars in Brazil: a chili pepper casestudy research. Hortic. Bras. 34:161-167.

Pinto CMF, Santos IC and Pinto FA (2011). Importância sócio-econômica da pimenta (Capsicum spp.). In: Produção, genética e melhoramento de pimentas (Capsicum spp.) (Rêgo ER, Finger FL and Rêgo MM). 1ª ed. Recife. Imprima, 137-164.

Potnis N, Timilsina S, Strayer A, Shantharaj D, et al. (2015). Bacterial spot of tomato and pepper: diverse Xanthomonas species with a wide variety of virulence factors posing a worldwide challenge. Mol. Plant Pathol. 16: 907-920. https://doi.org/10.1111/mpp.12244

Potnis N, Minsavage G, Smith JK, Hurlbert JC, et al. (2012). Avirulence proteins AvrBs7 from Xanthomonas gardneri and AvrBs1.1 from Xanthomonas euvesicatoria contribute to a novel gene-for-gene interaction in pepper. Mol. Plant Microbe Interact. 25: 307-320. https://doi.org/10.1094/MPMI-08-11-0205

Reis A, Boiteux LS and Henz GP (2009). Antracnose em Hortaliças da Família Solanacea. Circular Técnico Embrapa Hortaliças. Brasília, Distrito Federal. Available at [http://ainfo.cnptia.embrapa.br/digital/bitstream/CNPH2010/36354/1/ct-79.pdf]. Accessed November 8, 2016.

Ribeiro CS, Souza KR, Carvalho SI and Reifschneider FJ (2015). BRS Juruti: the first Brazilian habanero-type hot pepper cultivar. Hortic. Bras. 33: 527-529. https://doi.org/10.1590/S0102-053620150000400020

Genetics and Molecular Research 16 (3): gmr16039789 
Riva EM, Rodrigues R, Pereira MG, Sudré CP, et al. (2004a). Inheritance of bacterial spot disease in Capsicum annuum L. Crop Breed. Appl. Biotechnol. 4: 490-494. https://doi.org/10.12702/1984-7033.v04n04a18

Riva EM, Rodrigues R, Sudré CP, Karasawa M, et al. (2004b). Three recessive genes controlling bacterial spot resistance in pepper. In 17th International Pepper Conference, Summary. Naples, USA. 21.

Riva-Souza EM, Rodrigues R, Sudré CP, Pereira MG, et al. (2009). Genetic parameters and selection for resistance to bacterial spot in recombinant $\mathrm{F}_{6}$ lines of Capsicum annuum. Crop Breed. Appl. Biotechnol. 9: 108-115. https://doi. org/10.12702/1984-7033.v09n02a02

Riva-Souza EM, Rodrigues R, Sudré CP, Pereira MG, et al. (2007). Obtaining pepper $\mathrm{F}_{2: 3}$ lines with resistance to the bacterial spot using the pedigree method. Hortic. Bras. 25: 567-571. https://doi.org/10.1590/S0102-05362007000400014

Rodrigues Neto J, Malavolta Júnior VA, Victor O (1986). Meio simples para o isolamento e cultivo de Xanthomonas campestris pv. citri tipo B. Sum. Phytopathol. 12: 16.

Ryan RP, Vorhölter FJ, Potnis N, Jones JB, et al. (2011). Pathogenomics of Xanthomonas: understanding bacterium-plant interactions. Natur. Rev. Microbiol. 9: 344-355.

Silva SA, Rodrigues R, Gonçalves LSA, Sudré CP, et al. (2014). Resistance in Capsicum spp. to anthracnose affected by different stages of fruit development during pre-and post-harvest. Trop. Plant Pathol. 39: 335-341. https://doi. org $/ 10.1590 / \mathrm{S} 1982-56762014000400009$

Souza CS, Paulsen BS, Devalle S, Costa SL, et al. (2015). Commitment of human pluripotent stem cells to a neural lineage is induced by the pro-estrogenic flavonoid apigenin. Advances in Regenerative Biology, [S.1.], dec. ISSN 2001-8517. (2015). Available at [http://www.regenerativebiology.net/index.php/arb/article/view/29244]. Accessed March 31, 2016.

Stall RE, Jones JB, Minsavage GV (2009). Durability of resistance in tomato and pepper to xanthomonads causing bacterial spot. Annual Rev. Phytopathol. 47: 265-284.

Strauß T, Poecke RMP, Strauß A, Römer P, et al. (2012). RNA-seq pinpoints a Xanthomonas TAL-effector activated resistance gene in a large crop genome. PNAS, 10.1073 .

Sun C, Mao SL, Zhang ZH, Palloix A, et al. (2015). Resistances to anthracnose (Colletotrichum acutatum) of Capsicum mature green and ripe fruit are controlled by a major dominant cluster of QTLs on chromosome P5. Sci. Hortic. 181: $81-88$.

Suwor P, Thummabenjapone P, Sanitchon J, Kumar S, et al. (2015). Phenotypic and genotypic responses of chili (Capsicum anпuи $\mathrm{L}$.) progressive lines with different resistant genes against anthracnose pathogen (Colletotrichum spp.). Europ. J. Plant Pathol. 143: 725-736.

Truta AA, Souza AR, Nascimento AVS, Pereira RDC, et al. (2004). Identidade e propriedades de isolados de potyvírus provenientes de Capsicum spp. Fitopatol. Bras. 29: 160-168. https://doi.org/10.1590/S0100-41582004000200007

Vallejos CE, Jones V, Stall RE, Jones JB, et al. (2010). Characterization of two recessive genes controlling reistance to all races of bacterial spot in peppers. Theoret. Appl. Genet. 121: 37-46.

Villalon-Mendoza H, Medina-Martinez T, Ramirez-Meraz M, Urbina SES, et al. (2014). Factors Influencing the Price of Chile Piquin wild Chili (Capsicum annuum L. var. glabriusculum) of North-east Mexico. Internat. J. Bio-res. Stress Manag. 5: 128-131.

Wai KPP, Siddique MI, Mo HS, Yoo HJ, et al. (2015). Pathotypes of Bacterial Spot Pathogen Infecting Capsicum Peppers in Korea. Plant Pathol. J. 31:428.

Ying SC, Li MS, Hai ZZ, Alainb P, et al. (2015). Resistances to anthracnose (Colletotrichum acutatum) of Capsicum mature green and ripe fruit are controlled by a major dominant cluster of QTLs on chromosome P5. Sci. Hortic. 181: 81-88.

Zipfel CB and Jones JDG (2015). Methods of enhancing the resistance of plants to bacterial pathogens. U.S. Patent $n$. 9,222,103, 29 dez. 2015.

Genetics and Molecular Research 16 (3): gmr16039789 